\title{
VLOGA FINANČNIH VIROV PRI UVELJAVLJANJU SODOBNE VARNOSTNE PARADIGME NA OBRAMBNEM PODROČJU V IZBRANIH DRŽAVAH
}

Povzetek Kompleksno varnostno okolje in izzivi sodobnega sveta, s katerimi se vsak dan srečujemo, predstavljajo rdečo nit članka, v katerem trdim, da se mora obrambni sistem kot del nacionalno-varnostnega sistema sodobne družbe nenehno prilagajati izzivom okolja, v katerem deluje. Kajti le njegovo stalno prilagajanje mu namreč omogoča učinkovito odgovoriti na izzive, ki jih prinašajo s seboj procesi globalizacije, tudi na področju varnosti. Izziv predstavlja področje organiziranosti obrambnih sistemov in finančnih virov, ki zagotavljajo njihovo delovanje po posameznih državah. Omenjeno področje je namreč v državah različno urejeno oziroma so se države večinoma različno lotile organiziranja oziroma prilagajanja sistema na izzive sodobnega okolja. Uspešnost njihovega prilagajanja bo merljiva šele čez čas. Ker strateški in usmerjevalni dokumenti določajo tudi preoblikovanje obrambnega sistema Slovenije, je smiselno upoštevati tudi primere dobre prakse in pristope, ki so jih uporabile izbrane države. Kajti le s pravočasnim in celovito izvedenim preoblikovanjem obrambnega sistema se bo zagotovila še učinkovitejša podpora obrambnemu sistemu in v potrebnem obsegu tudi sistemu varstva pred naravnimi in drugimi nesrečami.

Ključne besede

A complex security environment and the challenges of modern world encountered every day, represent the main theme of this article. I argue that the defence system, as part of a modern national security system, should continuously adapt to the challenges of its operational environment. Only continuous adaptation will enable it to effectively respond to the challenges engendered by globalisation processes, also in the security domain. The organisation of defence systems and financial resources facilitating their functioning in individual countries are a challenge. The regulation of this subject area varies from country to country, or better, the countries have adopted 
different ways to approach organisation and adaptation of the system to the challenges of the modern environment. However, the results of their adjustment will not be measurable until after a while. Since the strategic and guidance papers also define the transformation of the defence system of the Republic of Slovenia, it is sensible to consider the examples of good practice and the approaches adopted by selected countries. Only timely and comprehensive transformation of the defence system will provide a more effective support to the defence system and, to the desired extend, to the system of protection against natural and other disasters.

Key words Modern security environment, globalised security, gross domestic product, financial resources, defence system, transformation of defence capabilities.

Uvod Ljudje vidimo in razumemo grožnje različno, odvisno od tega, kje in v kakšnih razmerah delujemo. Tako se v mednarodnem in nacionalnovarnostnem okolju 21. stoletja soočamo z različnimi viri ogrožanja in tveganja varnosti, ki se z geografskega vidika pojavljajo tako na nacionalni, nadnacionalni in na globalni ravni (ReSNV, 2010). Gre za kompleksne, soodvisno oziroma neodvisne, sinergične, medsebojno povezljive, največkrat težko predvidljive $\mathrm{z}$ multiplikatorskim učinkom in naravo, nosilci pa so večinoma nedržavni subjekti. Na takšno dojemanje sodobnega varnostnega okolja in posledično razumevanje varnosti vplivajo tudi številni procesi, ki so v mednarodnih odnosih tako na regionalni kot na svetovni ravni povzročili vrsto pomembnih premikov, sprožili številne procese in temeljito preuredili politično in tudi varnostno podobo Evrope (Stelle, 2002).

Svoje so, k spreminjajočim se varnostnim tveganjem in grožnjam, dodali tudi globalizacija, univerzalizacija in informacijska revolucija ter posledično visoka stopnja soodvisnosti, ki s svojimi procesi prinašajo tudi vsa tveganja oziroma povečujejo svoj vpliv na stopnjo in posledično tudi na ceno, ki jo zahteva varnost. Torej, večji kot so učinki in posledice globalizacijskih procesov, večja sta raznovrstnost in vpliv sodobnih varnostnih tveganj in groženj na varnost različnih referenčnih objektov. Na podlagi tega lahko povzamem, da sta globalizacija in varnost v medsebojni soodvisnosti in premosorazmernosti. Drugače povedano, višja sta tveganje in ogroženost, višja je cena varnosti, kar pomeni, da se tudi varnost, ne samo v finančnem, temveč tudi v geostrateškem pomenu, posledično vse bolj globalizira in postaja globalizirana varnost.

Zaznavanje in razumevanje varnosti je v sodobni družbi podrejeno spremenjenim oblikam virov ogrožanja, ki razumevanje in preučevanje varnosti premikajo od tradicionalnih, pri čemer je v ospredju varnost države oziroma nacionalna varnost, $\mathrm{k}$ sodobnim oblikam preučevanja, ki se nanašajo predvsem na varnost posameznika in mednarodne skupnosti. Varnostno okolje je imelo v preteklosti bolj vojaškopolitične razsežnosti, danes pa je bolj v ospredju širša socialna in kulturno-civilizacijska dimenzija (Grizold, 2005, str. 7). 
Vsa ta raznovrstnost procesov in spremljajočih učinkov, tudi varnostnih tveganj, ki jih prinašajo nagle spremembe $\mathrm{v}$ družbi, po drugi strani pa tudi nove priložnosti in izzivi so v znamenju nove, sodobne varnostne paradigme sprožili številne neustavljive procese znotraj obstoječih sistemov nacionalne varnosti, ki spreminjajo vlogo države pri zagotavljanju varnosti njenih državljanov oziroma prebivalcev. Prizadevanje za vzpostavitev varnosti je civilizacijska in kulturna kategorija, ki zajema vse vidike varnosti, med drugim tudi gospodarsko, socialno, politično, pravno in obrambno. Lahko rečemo, da pojem varnosti obsega družbene vrednote na regionalni, nacionalni, mednarodni in svetovni ravni (Anžič, 1997, str. 35).

Sodobna varnostna paradigma obravnava varnost $\mathrm{v}$ treh temeljnih konceptualnih okvirih, in sicer kot individualno, nacionalno in mednarodno varnost. Če je individualna potreba po varnosti, ki jo čuti posameznik, zagotovljena in tudi zadovoljena, so mu omogočeni kakovosten razvoj, obstoj ter delovanje v družbi in naravi (Brezovšek in Črnčec, 2007, str. 17). Varnost je zato družbeni fenomen, ki se nanaša na vse entitete, tako na posameznika kot na vse organizacijske oblike združevanja in povezovanja na kateri koli ravni, v katere se vključuje. Sodobna varnostna razprava je tako danes usmerjena predvsem na tri varnostne referenčne objekte, ki so: na koga se varnost nanaša, kdo oziroma kaj to varnost ogroža in seveda katere varnostne mehanizme uporabiti za zagotovitev ustrezne stopnje varnosti (Liotta v Svete, 2005, str. 55).

Postmoderni ali bolj kompleksni pristopi obravnavanja varnosti, kjer se v razpravo o varnosti začnejo uvrščati tudi nedržavni akterji, je zaslediti v začetku sedemdesetih let prejšnjega stoletja. Vendar pa novo oziroma sodobno razumevanje varnosti lahko pripišemo koncu hladne vojne in procesom v mednarodni skupnosti, ki so sledili, ko se med referenčnimi objekti vse bolj izpostavljata človek in njegova varnost. Vse bolj legitimne pa so postajale tudi razprave o varnostnih subjektih, varnosti kot emancipaciji, nevarnostni dilemi, družbeni in človekovi varnosti ter družbi tveganja (Newman v Svete, 2005, str. 57). Omenjene bolj kompleksne varnostne opredelitve je treba razumeti kot posledico naglega družbenega razvoja in spremenjenega mednarodnega okolja ter spremenjenega tradicionalnega koncepta ogrožanja.

Veliko število referenčnih objektov nas lahko vodi do ugotovitve, da v sodobnih varnostnih študijah ne moremo govoriti o konsenzu in kdo so referenčni objekti, saj med njimi obstaja prevelika prepletenost in soodvisnost, prav tako pa ne moremo določiti virov ogrožanja na samo določen referenčni objekt. Poleg tega je treba upoštevati, da referenčni objekti niso nujno samo objekti ogrožanja, ampak so lahko tudi potencialni viri ogrožanja drugim referenčnim objektom. Na podlagi tega lahko sklepam, da je to obdobje zaznamovano s povečanjem števila nevojaških virov ogrožanja, hkrati pa tudi s povečanjem števila referenčnih objektov, ki so potencialno ogroženi. Nova razumevanja varnosti in njenega ogrožanja bodo v prihodnje lahko nastajala le zaradi povečanja števila referenčnih objektov in ne toliko zaradi virov ogrožanja, pa naj bodo dejanski ali zaznani. 
Za zagotavljanje varnosti je torej treba zagotoviti tudi finančne vire, ki pa jih $\mathrm{v}$ sodobnem spreminjajočem se okolju množično primanjkuje oziroma ne moremo govoriti o njihovi sorazmerni porazdelitvi. Eden od razlogov za takšno stanje je tudi globalizacija, za katero Lechner (2009, str. 15-16) pravi, da je »proces, v katerem se vse več ljudi povezuje na najrazličnejše načine na velikih razdaljah. Nanaša se na transplanetarne in zadnje čase vedno bolj suprateritorialne povezave med ljudmi, kar vključuje zmanjšanje meja pa vse do transsvetovnih družbenih stikov«.

Eno od oblik globalizacije, ki je v tesnejši povezavi s finančnimi viri, predstavlja ekonomska globalizacija. Bhagwati (2004, str. 3) je ekonomsko globalizacijo opredelil kot obliko integracije nacionalnih gospodarstev v mednarodno gospodarstvo s pomočjo mednarodne trgovine, menjave in proizvodnje, neposrednih tujih investicij, kratkoročnih pretokov kapitala, mednarodne migracije delovne sile in prenosa tehnologije. Takšno razumevanje globalizacije pomeni močan poudarek na ekonomski učinkovitosti, novih znanjih in idejah, tržnem vedenju in ravnanju, globalni tržni konkurenci, spodbujanju neposrednih tujih investicij in učinkoviti alokaciji proizvodnih dejavnikov.

Globalizacijo razumemo tudi kot liberalizacijo, pri čemer gre za procese mednarodnega ekonomskega povezovanja, $v$ katerih so politične ovire za trgovanje in investicije v globalni ekonomiji med državami odpravljene. Povezuje pa se tudi s pojmom deteritorizacije v smislu reorganizacije družbenega prostora, ki ga ne obvladuje več teritorialni prostor oziroma teritorialne meje, kar pomeni zniževanje trgovinskih ovir, hkrati pa napredek v transportu, pretoku virov in kapitala ${ }^{1}$, storitev, tehnologije, idej, informacij in komunikacij, kar omogoča razpršitev dejavnosti po vsem svetu in ustvarjanje ekonomije obsega (Kovač in drugi, 2008, str. 54).

Ekonomska globalizacija ni nezadržen oziroma nepovraten proces in njen vpliv ni kratkotrajen. Povzroča namreč dolgoročne strukturne spremembe v svetovnem gospodarstvu, še posebej $\mathrm{v}$ naravi in obsegu integracije različnih dejavnikov, vlaganj in končnih trgov. Večina teoretikov (Kovač in drugi, 2008, str. 59) meni, da ekonomska globalizacija postavlja nove izzive pred nacionalno državo. Hitro rastoči trgi so ponekod povzročili, da so nacionalne države že izgubile oziroma počasi izgubljajo primat, svojo moč in avtonomijo ter imajo vse manj nadzora in vpliva nad družbenimi in ekonomskimi procesi na svojem tradicionalnem prostoru. Liberalizacija, privatizacija in deregulacija namreč spreminjajo tradicionalno vlogo nacionalne države. Tudi po mnenju Rizmana (2001, str. 31) lahko na dolgoročno preživetje in razvoj računajo samo tiste nacionalne države, ki so se pripravljene

\footnotetext{
Negri in Hardt (2009) menita, da danes v svetu gospoduje finančna industrija, pri čemer so finance »življenjska tekočina proizvodnje, razvoja in izkoriščanj industrijskega dela in se tako izogibajo demokratičnemu nadzoru. Po njunem mnenju so danes finance absolutistični sistem, finančni trgi pa popolnoma superiorni, nedotakljivi in samoregulirajoči. Realno razmerje moči utemeljuje tudi s tem, da je finančna agencija Standard\&Poor's, $k i$ sledi finančnim tokovom in spremlja vrednost obveznic, med drugimi tudi $Z D A$, zagrozila z znižanjem ratinga obveznic ameriškega javnega dolga oziroma njihovim razvrednotenjem. Zanimivo je tudi njuno razmišljanje o kapitalizmu, ki je na začetku šel skozi prvobitno akumulacijo, v kateri je država služila kapitalu. Pozneje je prišlo do poistovetenja kapitala in države oziroma družbene ureditve. Danes pa se je kapital močno dvignil nad državo in vzpostavlja svoj neodvisen sistem, urejata pa ga finančni trg in ustvarjanje finančnih instrumentov.
} 
prilagoditi in modernizirati tako v svojem notranjepolitičnem kot tudi v mednarodnem prostoru. Stari tip nacionalnih držav v sodobnem mednarodnem okolju namreč ne more obstati, saj sodobni izzivi zahtevajo drugačne okvire delovanja nacionalne države.

V tako kompleksnem, dinamičnem, soodvisnem, podvrženem nepredvidljivim spremembam z globalnimi razsežnostmi, sodobnem mednarodnem varnostnem okolju, upoštevajoč raznovrstnost in multiplikativnost sodobnih virov ogrožanja in tveganja varnosti, si nobena država ne more več zagotavljati svoje nacionalne varnosti povsem samostojno in neodvisno od drugih. Tudi z vidika omejenih finančnih virov za razvoj potrebnih vojaških zmogljivosti je nujno povezovanje in partnersko sodelovanje ter večnacionalno sodelovanje $\mathrm{v}$ različnih projektih. Temu se ni mogla izogniti niti Republika Slovenija, ki si je leta 2004 z vstopom v EU in Nato, dveh ključnih dejavnikov zagotavljanja miru in stabilnosti na evro-atlantskem prostoru, zagotovila vstop v družbo, ki zagotavlja dolgoročno stabilnost, pomoč, sodelovanje in varnost tako na regionalni ravni kot tudi širše.

Dokaz več, da je mednarodno okolje zelo kompleksno in zahteva multidisciplinarni pristop ter stalno prilagajanje novim grožnjam in varnostnim izzivom, je tudi leta 2010 sprejeti novi Strateški koncept Nata. Odločitve na vrhu v Lizboni so bile med drugim povezane predvsem s strukturnimi reformami, transformacijo zmogljivosti, z zavezanostjo načelom ustanovne listine Organizacije združenih narodov ter z nadaljevanjem krepitve odnosov z EU in politiko odprtih vrat zavezništva. V duhu zavedanja o pomembnosti varnostne situacije in kot izhod iz trenutnih razmer je generalni sekretar Nata, A. F. Rasmussen, že leta 2011 na Varnostni konferenci v Münchnu v imenu Nata dal pobudo: »Zavedam se, da v dobi zmernosti ne moremo porabiti več, toda ne smemo porabiti manj. Torej odgovor je, porabiti bolje in dobiti več za isto vrednost ter tako pomagati članicam zavarovati njihove zmogljivosti in pridobiti nove. To pomeni, da moramo določiti prioritete, specializirati svoje sile in poiskati večnacionalne rešitve. Gledano v celoti, to imenujem Pametna obramba ${ }^{2}$."

Vpliv finančnih virov pri uveljavljanju sodobne varnostne paradigme na obrambnem področju s poudarkom na obrambnih zmogljivostih v izbranih državah bo v nadaljevanju predstavljen s pomočjo primerjalne metode, s katero bom prikazal finančne vire, ki jih države namenjajo za delovanje tega področja, ter vplive, podobnosti in razlike, ki jih prinašajo gibanja spreminjanja finančnih sredstev, namenjenih za delovanje obrambnih sistemov. Vpliv in uveljavljanje sodobne varnostne paradigme

\footnotetext{
Angl. SMART DEFENCE. Pobuda je dostopna na http://www. nato. Int.cps/en/natolive/78125.htm. Kot je razumeti, pri tej pobudi ne gre le za varčevanje, ampak predvsem za bolj učinkovito in smotrno oblikovanje zmogljivosti, potrebnih za optimalno delovanje, upoštevajoč razpoložljive finančne vire. Skladno s to pobudo bo združevanju zmogljivosti sledilo tudi zmanjševanje birokratskega aparata in racionalizacija poveljniške strukture, ki je sledila zahtevam po vzpostavitvi robustne strukture poveljevanja in kontrole, s ciljem ohranjanja obstoječe ravni ambicij, prilagodljivosti, optimizaciji in operacionalizaciji procesov delovanja, premestljivosti in večnacionalnosti. S to pobudo je Nato pozval svoje članice ter druge zaveznice k celostnemu pristopu, $k i$ bo kljub nastalim razmeram zagotovil skupno in učinkovito delovanje zavezništva tudi v prihodnje. Omenjeno pobudo razumemo kot odgovor na trenutne gospodarske razmere in zniževanje obrambnih proračunov, ki posledično ne dopuščajo podvajanja obrambnih zmogljivosti.
} 
bo najbolje razviden iz prikaza trendov zagotavljanja finančnih virov, ki se namenjajo za gradnjo in operabilnost obrambnih zmogljivosti v izbranih državah. Analiza in sekundarna interpretacija statističnih rezultatov bo predstavljala pomembno kvalitativno metodo, s katero bom različne statistične podatke iz domačih in tujih virov ustrezno analiziral. V povezavi s predhodno navedeno metodo bom uporabil tudi analitično-sintetično metodo, s katero bom podrobneje analiziral različne pisne vire in poskusil s primerjalno analitičnim pristopom poiskati skupne točke in jih tudi ustrezno ovrednotiti.

Skozi ves članek pa bosta nedvomno nepogrešljiva induktivni način raziskovanja, ki bo uporabljen pri sklepih, povzetkih in osebnih razmišljanjih, s katerimi bom postavil v celotno analizo nekaj ključnih ugotovitev, in deduktivni način raziskovanja, ki bo uporabljen predvsem v vsebinskem delu.

Na podlagi tehtnega premisleka in v smislu doseganja relevantnih ter primerljivih rezultatov $^{3}$ sem za primerjavo izbral te države:

\begin{tabular}{|c|c|c|c|c|c|c|}
\hline \multirow{6}{*}{$\begin{array}{l}\text { Tabela 1: } \\
\text { Izbrane države }\end{array}$} & $\begin{array}{l}\text { Zap. } \\
\text { št. }\end{array}$ & Država & $\begin{array}{l}\text { Sosednja } \\
\text { država }\end{array}$ & $\begin{array}{l}\text { Članica } \\
\text { Nata }\end{array}$ & $\begin{array}{c}\text { Nevtralna } \\
\text { država }\end{array}$ & $\begin{array}{c}\text { Obvezno služenje } \\
\text { vojaškega roka }\end{array}$ \\
\hline & 1. & Republika Avstrija & $x$ & & $x$ & $x$ \\
\hline & 2. & Republika Italija & $x$ & $x$ & & \\
\hline & 3. & Republika Madžarska & $x$ & $x$ & & \\
\hline & 4. & Republika Hrvaška & $x$ & $x$ & & \\
\hline & 5. & Republika Slovenija & & $x$ & & \\
\hline
\end{tabular}

Iz izbranih držav je razvidno, da gre za štiri sosednje države in Slovenijo, od katerih so Italija, Hrvaška in Madžarska članice Nata in imajo poklicno vojsko, medtem ko ima Avstrija status nevtralnosti in še vedno obvezno služenje vojaškega roka.

Za primerjalno analizo navedenih držav je izbrano obdobje od leta 2005 naprej, po tem, ko je Slovenija leta 2004 postala polnopravna članica EU in zveze Nato. Podatki o različnih kazalnikih v izbranih državah so pridobljeni iz The Military Balance 2005-2012 (The International Institute for Strategic Studies (IISS)), ki se

\footnotetext{
3 Dobljeni rezultati bodo zaradi lažjega in pravilnega razumevanja predstavljeni v grafični podobi. Po zaključeni raziskavi oziroma zbiranju kvantitativnih podatkov iz izbranih medsebojno primerjanih držav bo sledila njihova smiselna ureditev $v$ preglednice in grafikone, obdelava z različnimi metodami ter njihova interpretacija.

${ }^{4}$ Na primeru višine BDP v USD Avstrije bom prikazal razlike, ki se pojavljajo pri zbiranju podatkov iz različnih virov. Po podatkih IHS Jane's Defense \& Security Intelligence \& Analysis je BDP: 370 mlrd., CIA The World Factbook: 376,8 mlrd., Global Finance: 405,6 mlrd. Razlike se torej gibljejo v razponu 1,8 in vse do 9,5 odstotka. Iz prikazanega lahko zaključim, da se razlike pojavljajo glede na institucijo, ki podatke zbira, predvsem v smislu uradna torej državna : zasebna. Omenjena trditev velja tudi za vse druge države, ki so bile zajete $v$ primerjalni analizi.
} 
je pri zbiranju podatkov izkazala za najbolj verodostojno, transparentno in primerljivo, medtem ko so podatki o trendu obrambnega proračuna ${ }^{5}$ za obdobje 2010-2015 in strukturi obrambnega sistema izbranih držav pridobljeni iz IHS Jane's: Defence \& Security \& Analysis. Podatki o finančnih kazalnikih so v Military Balance navedeni v USD, vendar sem jih zaradi lažje primerjave med izbranimi državami predstavil v evrih ${ }^{6}$.

Ključni finančni kazalniki, ki bodo prikazani in analizirani, so: bruto družbeni proizvod v znesku - BDP, bruto družbeni proizvod per capita oziroma na prebivalca v evrih (izraženo v 1000) - BDP pc, višina obrambnega proračuna v evrih - OP in višina obrambnega proračuna v odstotkih BDP - OP (\%).

\section{VPLIV FINANČNIH VIROV NA OBRAMBNE ZMOGLJIVOSTI REPUBLIKE AVSTRIJE}

Nosilec izvajanja obrambne politike Republike Avstrije je ministrstvo za obrambo in šport (v nadaljevanju MO), ki je poleg nacionalne obrambe odgovorno tudi za avstrijsko zvezno vojsko. Vrhovni poveljnik avstrijskih oboroženih sil je po ustavi predsednik države. Avstrijske oborožene sile predstavlja avstrijska zvezna vojska (v nadaljevanju AZV).

Na podlagi analize ključnih finančnih kazalnikov obrambnega sistema Avstrije, ki zagotavljajo izvajanje njegovega poslanstva in nalog, predstavljam te ugotovitve.

\begin{tabular}{|l|c|c|c|c|c|c|c|}
\hline $\begin{array}{l}\text { Finančni } \\
\text { kazalniki }\end{array}$ & 2005 & 2006 & 2007 & 2008 & 2009 & 2010 & 2011 \\
\hline BDP & $245 \mathrm{mlrd}$. & $262 \mathrm{mlrd}$. & $270 \mathrm{mlrd}$. & $282 \mathrm{mlrd}$. & $281 \mathrm{mlrd}$. & $284 \mathrm{mlrd}$. & $301 \mathrm{mlrd}$. \\
\hline BDP pc & 29,9 & 32 & 31,9 & 34,5 & 30,5 & 33,9 & 36,7 \\
\hline OP & $1,81 \mathrm{mlrd}$. & $1,81 \mathrm{mlrd}$. & $2,25 \mathrm{mlrd}$. & $2,03 \mathrm{mlrd}$. & $2,11 \mathrm{mlrd}$. & $2,12 \mathrm{mlrd}$. & $2,06 \mathrm{mlrd}$. \\
\hline OP $(\%)$ & 0,73 & 0,69 & 0,83 & 0,72 & 0,77 & 0,75 & 0,68 \\
\hline
\end{tabular}

V Avstriji in Hrvaški je finančno breme za potrebe obrambnega sistema izraženo v obrambnem proračunu, zato bom za ustrezno in enotno primerjavo z drugimi državami upošteval le obrambni proračun in ne obrambnih izdatkov.

${ }^{6}$ Pri valutni menjavi USD v EUR oziroma državne valute v USD in pozneje v EUR je upoštevano takratno veljavno valutno razmerje, ki je prav tako navedeno v Military Balance. Leta 2005 je bilo valutno razmerje (USD1 = 0,79), leta 2006 (USD1 = 0,78), leta 2007 (USD1 = 0,70), leta 2008 (USD1 = 0,74), leta 2009 (USD1 $=0,67)$, leta $2010($ USD1 $=0,76)$ in leta $2011($ USD1 $=0,71)$. 


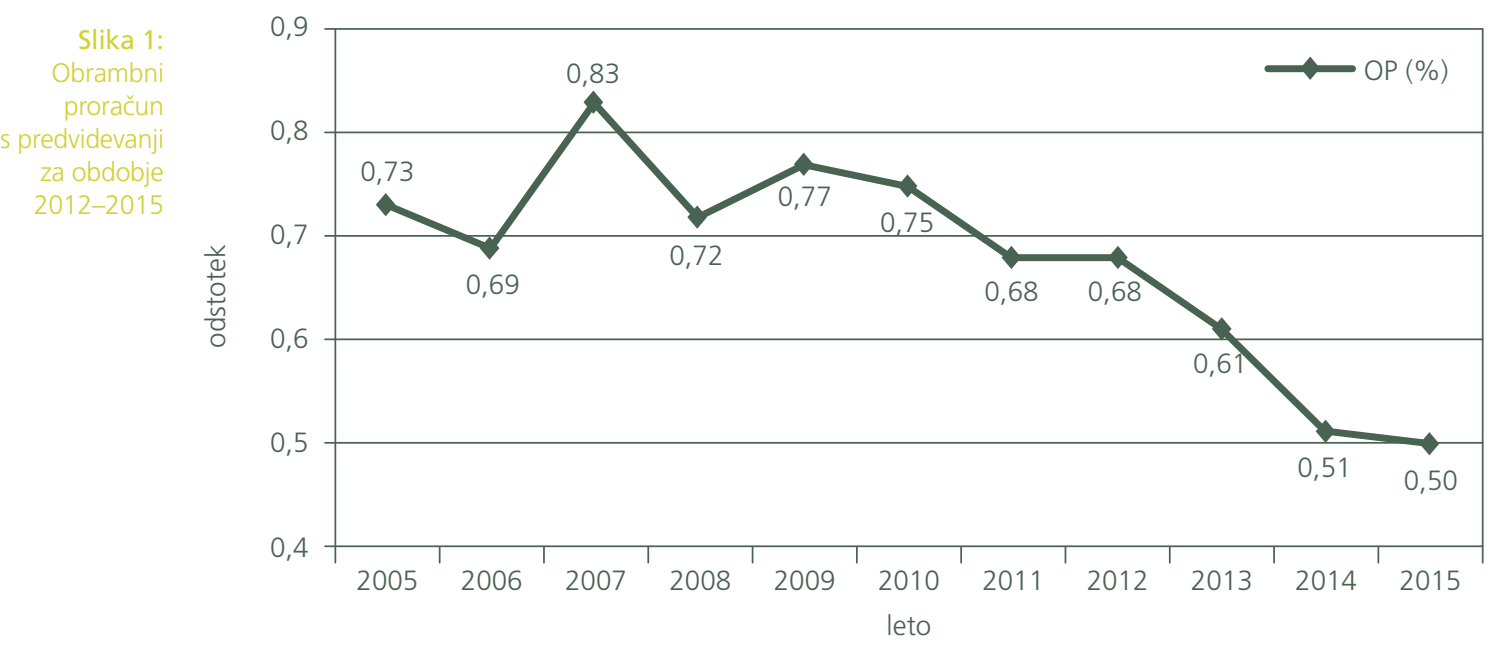

Višina obrambnega proračuna je ena od najnižjih med državami članicami EU. Kot je razvidno (slika 1), predvidevanja nakazujejo še dodatno 30-odstotno znižanje (približno 600 mio. evrov) do leta 2015, kar bo znatno otežilo poskuse preoblikovanja avstrijske zvezne vojske v izključno poklicno vojsko. Zaradi skoraj 10-odstotnega znižanja proračuna v obdobju 2008-2010 je prišlo tudi do zmanjšanja mirnodobne sestave, delno tudi na račun zmanjšanja števila vojakov na služenju vojaškega roka. Na obdobje po letu 2010 so prestavljene tudi številne načrtovane zamenjave oziroma modernizacija oborožitvenih sistemov. Zaradi padajočega trenda obrambnega proračuna, po podatkih Military Balance 2012, v ministrstvu za obrambo Avstrije načrtujejo nadaljnje prolongiranje modernizacije oborožitvenih sistemov, zmanjševanje števila pripadnikov avstrijske zvezne vojske v MOM in odprodajo nepremičnin. Načrtovano pa je tudi preoblikovanje vojske.

Prednostne naloge na obrambnem področju, skladne z razpoložljivimi finančnimi viri, so:

1. Kot določajo strateško-usmerjevalni dokumenti, naj bi imel obrambni sistem Avstrije poleg 21.000 pripadnikov mirnodobne sestave še rezervno sestavo s 24.000 pripadniki. Število preostalih zaposlenih na ministrstvu za obrambo in šport pa naj bi bilo 10.000. Torej vse skupaj 55.000.

2. Naborniški sistem bo predvidoma ostal temelj obrambno-varnostne politike, večjo pozornost pa nameravajo nameniti posodobitvi rezervne sestave in služenju vojaškega roka.

3. Poleg tega bodo v prihodnje večjo pozornost namenili sodelovanju z evropskimi partnerji na področju skupnih sil in izkoriščanju skupnih kapacitet, s čimer želijo povečati učinkovitost in zmanjšati stroške v okviru operacij EU in v okviru sodelovanja pri konceptu evropskih bojnih skupin (EUBG).

4. Poslanstvo in naloge avstrijske zvezne vojske naj bi se večinoma preusmerile z varovanja suverenosti (v okviru vojaške obrambe države) na zagotavljanje 
pomoči ob naravnih in drugih nesrečah ${ }^{7}$ ter na sodelovanje v okviru evropskega kriznega menedžmenta.

5. Spremembe namembnosti zahtevajo spremembe na kadrovskem področju, na področju opremljanja, predvsem pa na področju prilagajanja zakonodaje, in sicer ustave, zakona o vojski in zakonodaje na področju delovnega prava.

\section{VPLIV FINANČNIH VIROV NA OBRAMBNE ZMOGLJIVOSTI REPUBLIKE ITALIJE}

Nosilec izvajanja obrambne politike Republike Italije je ministrstvo za obrambo (v nadaljevanju MO), ki je odgovorno tudi za civilno obrambo in meteorologijo. Vrhovni poveljnik italijanskih oboroženih sil je po ustavi predsednik republike oziroma Vrhovni svet za obrambo, kateremu predseduje predsednik republike. Če bi prišlo do vojne, pa je vrhovni poveljnik predsednik vlade. Italijanske oborožene sile predstavlja italijanska vojska.

Na podlagi analize ključnih finančnih kazalnikov obrambnega sistema Italije, ki zagotavljajo izvajanje njegovega poslanstva in nalog, predstavljam te ugotovitve:

\begin{tabular}{|c|c|c|c|c|c|c|c|c|}
\hline \multirow{5}{*}{$\begin{array}{r}\text { Tabela 3: } \\
\text { Ključni kazalniki } \\
\text { obrambnega } \\
\text { sistema Italije }\end{array}$} & $\begin{array}{l}\text { Finančni } \\
\text { kazalniki }\end{array}$ & 2005 & 2006 & 2007 & 2008 & 2009 & 2010 & 2011 \\
\hline & BDP & 1370 mlrd. & 1470 mlrd. & 1550 mlrd. & $1610 \mathrm{mlrd}$. & 1510 mlrd. & 1560 mlrd. & $1590 \mathrm{mlrd}$. \\
\hline & BDP pc & 23,6 & 25,2 & 26,7 & 27,6 & 26,1 & 28,1 & 25,9 \\
\hline & OP & $14 \mathrm{mlrd}$ & $12,1 \mathrm{mlrd}$ & $12,4 \mathrm{mlrd}$ & $15,4 \mathrm{mlrd}$. & $15,4 \mathrm{mlrd}$ & $15,5 \mathrm{mlrd}$ & $15 \mathrm{mlrd}$ \\
\hline & OP (\%) & 1,017 & 0,82 & 0,79 & 0,96 & 1,01 & 0,99 & 0,99 \\
\hline
\end{tabular}

V celotnem primerjanem obdobju, od leta 2005 do leta 2011, je zaznati nihanja V višini $20 \%$ znotraj obrambnega proračuna. Tudi prikazana gibanja (slika 2) ne kažejo na povišanje oziroma se do leta 2015 predvideva še dodatno znižanje na vsega 0,9 \% BDP oziroma za padec v višini $10 \%$. Leta 2011 se je, zunaj obrambnega proračuna, za nemoteno operativno delovanje in javna naročila zagotovilo dodatnih 1,5 mio. evrov finančnih sredstev.

Za potrebe stroškov osebja se namenja 65,4 \% obrambnega proračuna, kar posledično zmanjšuje finančne vire za operacije in pripravljenost ter investicije. Posegi v stroške in plače pripadnikov italijanske vojske trenutno niso predvideni. Za usposabljanje in operacije se namenja $10,4 \%$ obrambnega proračuna, kar je znatno manj

\footnotetext{
Avstrijska zvezna vojska na tem področju prevzema vse večji pobudo in odgovornost. Vse bolj aktivna pa je tudi pri pomoči ogroženim prebivalcem v obliki zagotavljanja oskrbe in transporta ter pri nalogah iskanja in reševanja ponesrečenih in pogrešanih.
} 
od predvidenih $30 \%$ in se lahko s takšnim padajočim gibanjem ogrozi operativna sposobnost vojske. Pojavlja se dilema, ali bodo posegi v zmanjšanje številčnosti v resnici omogočili posodabljanje vojske. Tudi Italija se srečuje z dejstvom, da je poklicna vojska, ob upoštevanju vseh primerljivih parametrov, občutno dražja od naborniške vojske.

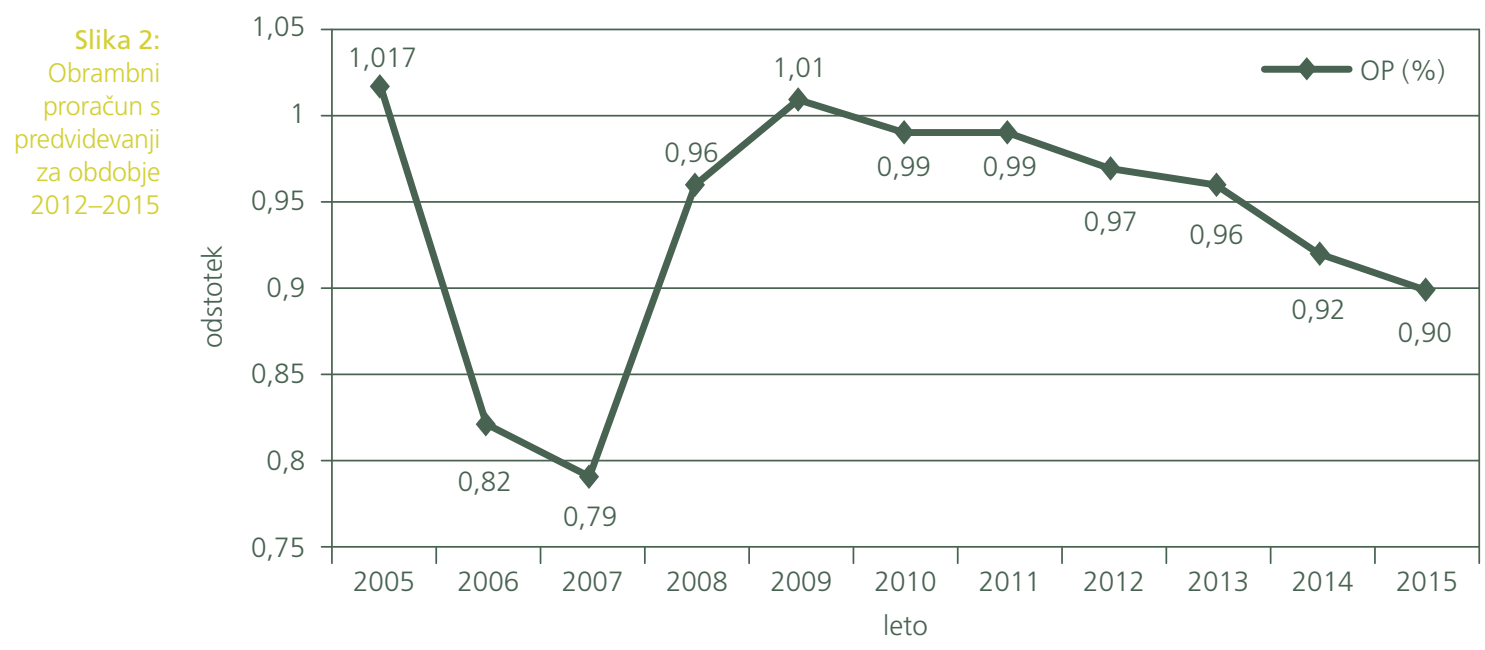

Poleg tega sta načrtovana še prolongiranje modernizacije oborožitvenih sistemov in nadaljnja odprodaja nepremičnin. Pri tem je treba stalno zagotavljati ravnotežje med posodabljanjem in vzdrževanjem, ki omogočata neprekinjenost tako operativnega delovanja kot naročanja za prihodnost. Zamuda pri katerem koli programu, vzdrževanje ali nova investicija lahko drastično vplivajo na operativnost sredstva, če mu poteče njegova operativna doba brez ustreznega vzdrževanja oziroma zamenjave.

Kljub zmanjševanju obrambnega proračuna se bodo, zaradi spreminjajoče se varnostne situacije ${ }^{8}$, finančni viri, namenjeni za delovanje karabinjerjev, povišali. To pomeni, da se bodo finančni viri znotraj obrambnega sistema prelocirali.

Prednostne naloge na obrambnem področju skladno z razpoložljivimi finančnimi viri so:

1. Za potrebe nacionalne obrambe bo Italija kot članica Nata še naprej sodelovala $\mathrm{z}$ zavezniškimi silami in si tako zagotavljala interoperabilnost, mobilnost, učinkovitost delovanja in vzdržljivost svojih zmogljivosti.

2. Predvsem zaradi nastale finančne situacije in zaradi pomanjkljivosti v operativni sposobnosti italijanske vojske bo Italija morala v bližnji prihodnosti revidirati

8 Povečano število ilegalnih migrantov, pritisk na meje Italije, povišana stopnja koruptivnosti in organiziranega kriminala. 
politiko in strategijo obrambnega modela ter obveznosti, izhajajočih iz zavezništev, ob hkratnem upoštevanju nacionalnega interesa.

3. Kljub stalnemu varčevanju in zmanjševanju obrambnega proračuna je treba zagotoviti polno integracijo med nacionalnimi vojaškimi komponentami, ohranjati visok operativni tempo delovanja in še naprej zagotavljati prisotnost ter interoperabilnost z zavezniškimi silami v multinacionalnih operacijah.

4. Po končani reformi naj bi mirnodobna sestava štela 150.000 pripadnikov, kar pomeni 18,4-odstotno zmanjšanje glede na sedanje število.

\section{VPLIV FINANČNIH VIROV NA OBRAMBNE ZMOGLJIVOSTI REPUBLIKE MADŽARSKE}

Nosilec izvajanja obrambne politike Republike Madžarske je ministrstvo za obrambo (v nadaljevanju MO). Vrhovni poveljnik madžarskih oboroženih sil je po ustavi predsednik države. Madžarske obrambne sile predstavlja madžarska vojska9

Na podlagi analize ključnih finančnih kazalnikov obrambnega sistema Madžarske, ki zagotavljajo izvajanje njegovega poslanstva in nalog, predstavljam te ugotovitve.

\begin{tabular}{|c|c|c|c|c|c|c|c|c|}
\hline \multirow{5}{*}{$\begin{array}{r}\text { Tabela 4: } \\
\text { Ključni kazalniki } \\
\text { obrambnega } \\
\text { sistema } \\
\text { Madžarske }\end{array}$} & $\begin{array}{l}\text { Finančni } \\
\text { kazalniki }\end{array}$ & 2005 & 2006 & 2007 & 2008 & 2009 & 2010 & 2011 \\
\hline & BDP & 86,9 mlrd. & $84,2 \mathrm{mlrd}$. & 102 mlrd. & 102 mlrd. & $93,1 \mathrm{mlrd}$ & $98,8 \mathrm{mlrd}$ & $\begin{array}{l}102,9 \\
\text { mlrd. }\end{array}$ \\
\hline & $\mathrm{BDP} p \mathrm{c}$ & 8,4 & 8,4 & 10 & 10 & 9,3 & 9,8 & 10,3 \\
\hline & OP & 1,12 mlrd. & $1,01 \mathrm{mlrd}$. & $1,26 \mathrm{mlrd}$ & 1,2 mlrd. & 1,24 mlrd. & 1,02 mlrd. & $1 \mathrm{mlrd}$. \\
\hline & OP (\%) & 1,41 & 1,20 & 1,23 & 1,17 & 1,33 & 1,03 & 0,97 \\
\hline
\end{tabular}

V celotnem primerjanem obdobju, od leta 2005 do leta 2011, je zaznati padec obrambnega proračuna v višini 26,9 \%, čeprav je v Nacionalni vojaški strategiji, sprejeti leta 2008, načrtovano povišanje obrambnega proračuna za 0,2 \% BDP v obdobju 20092013. Zaradi občutnega zmanjšanja obrambnega proračuna, kot posledice rebalansa celotnega proračuna, po podatkih Military Balance 2011, na MO Madžarske načrtujejo prolongiranje modernizacije oborožitvenih sistemov ${ }^{10} \mathrm{v}$ višini 20 -odstotnega obrambnega proračuna in odprodajo nepremičnin. Posegi v stroške in plače pripadnikov trenutno niso predvideni.

\footnotetext{
-V vojni oziroma v primeru konflikta se enote mejne straže, ki štejejo 12.000 pripadnikov, pridružijo sestavi obrambnih sil Madžarske. V mirnodobnem času so te enote v sestavi policije.

${ }^{10}$ Načrtovani so posodobitev letalskih zmogljivosti, nabava novih vojaških vozil in nadgradnja komunikacijskoinformacijskih sistemov.
} 


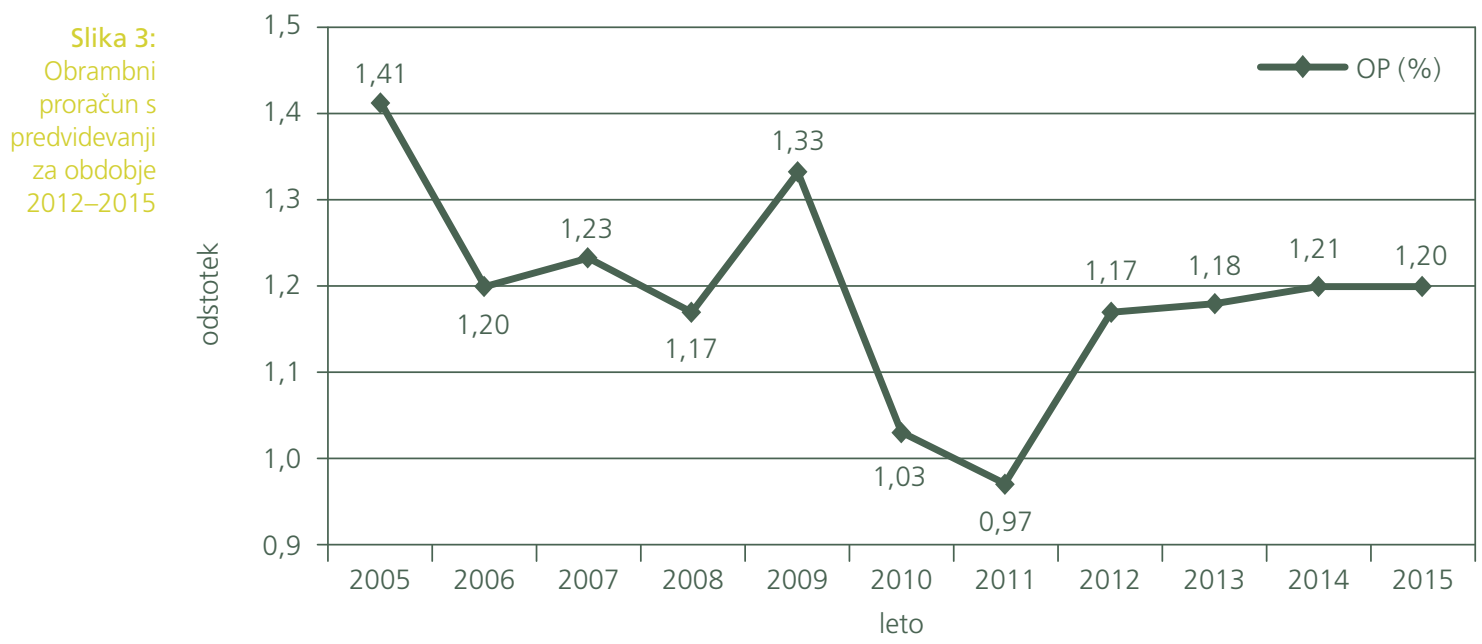

Tudi Madžarska se srečuje z dejstvom, da je poklicna vojska, ob upoštevanju vseh primerljivih parametrov, občutno dražja od naborniške vojske.

Prednostne naloge na obrambnem področju skladno z razpoložljivimi finančnimi viri so:

1. Po podatkih iz Military Balance 2012 se v bližnji prihodnosti načrtujejo preoblikovanje oziroma nova organizacijska struktura obrambnega štaba, spremembe v obrambnem načrtovanju, povečanje diplomatskih aktivnosti s partnerskimi državami, preoblikovanje vojaškega zdravstvenega sistema, spremembe pri usposabljanju častniškega kadra, pregled stanja v podjetjih, s katerimi ima MO Madžarske pogodbe za opravljanje različnih storitev ipd.

2. Izhajajoče naloge iz Strateškega pregleda obrambe iz leta 2003 in Smernic za delovanje obrambnega sistema iz leta 2005 ostajajo nespremenjene ${ }^{11}$.

3. Varčevalni ukrepi v nobenem primeru ne smejo vplivati na pripravljenost za delovanje in izvajanje dolgoročnih načrtov ${ }^{12}$.

4. Razvoj kopenske zvrsti zaradi vzpostavitve premestljive brigade in razvoj obveščevalnih zmogljivosti.

\footnotetext{
${ }^{\prime \prime}$ Naštel bom samo nekaj ključnih: delovanje skladno s V. členom Natove pogodbe, vključno z vojaško obrambo Madžarske in pomoč drugim državam članicam v primeru skupne obrambe; podpora pri izvajanju nalog varovanja meje; podpora države gostiteljice; sodelovanje pri mednarodnih aktivnostih zoperstavljanja terorizmu; podpora predstavnikom civilne oblasti, vključno z nalogami iskanja in reševanja, odkrivanju in uničevanj eksplozivnih sredstev in sodelovanje pri aktivnostih odpravljanja posledic naravnih in drugih nesreč ipd.

${ }_{12}$ Skladno z Nacionalno vojaško strategijo se načrtuje zaposlitev do 3000 pripadnikov, kar bi pomenilo razbremenitev obstoječih kadrovskih virov za izvajanje nalog v MOM. Prav tako omenjena strategija predvideva vzpostavitev prostovoljnega služenja vojaškega roka in sistema prostovoljne pogodbene rezerve, pri čemer bi do leta 2014 podpisali pogodbe s 4000 pripadniki. Prostovoljna pogodbena rezerva z možnostjo vpoklica $v$ primerih vojne in izrednih razmer naj bi postopoma nadomestila sedanjo rezervno sestavo.
} 


\section{VPLIV FINANČNIH VIROV NA OBRAMBNE ZMOGLJIVOSTI REPUBLIKE HRVAŠKE}

Nosilec izvajanja obrambne politike Republike Hrvaške je ministrstvo za obrambo (v nadaljevanju MO), ki je poleg nacionalne obrambe odgovorno tudi za hrvaško vojsko. Vrhovni poveljnik hrvaških oboroženih sil je po ustavi predsednik države. Hrvaške oborožene sile predstavlja hrvaška vojska.

Na podlagi analize ključnih finančnih kazalnikov obrambnega sistema Republike Hrvaške, ki zagotavljajo izvajanje njegovega poslanstva in nalog, predstavljam ugotovitve:

\begin{tabular}{|c|c|c|c|c|c|c|c|c|}
\hline \multirow{5}{*}{$\begin{array}{r}\text { Tabela 5: } \\
\text { Ključni kazalniki } \\
\text { obrambnega } \\
\text { sistema Hrvaške }\end{array}$} & $\begin{array}{l}\text { Finančni } \\
\text { kazalniki }\end{array}$ & 2005 & 2006 & 2007 & 2008 & 2009 & 2010 & 2011 \\
\hline & BDP & $30,2 \mathrm{mlrd}$ & $33,3 \mathrm{mlrd}$ & $36,3 \mathrm{mlrd}$ & $42,1 \mathrm{mlrd}$ & $45,1 \mathrm{mlrd}$ & $48,1 \mathrm{mlrd}$ & $46,3 \mathrm{mlrd}$ \\
\hline & BDP pc & 6,7 & 7,4 & 8 & 9,4 & 10 & 10,4 & 10,3 \\
\hline & OP & 494 mio. & 555 mio. & 612,5 mio. & 712 mio. & 683 mio. & 655,8 mio. & 663,8 mio. \\
\hline & OP (\%) & 1,63 & 1,66 & 1,68 & 1,68 & 1,51 & 1,41 & 1,43 \\
\hline
\end{tabular}

$\mathrm{Z}$ začetkom temeljitih reform in $\mathrm{z}$ vstopom $\mathrm{v}$ Nato bi pričakovali povišanje BDP-ja za potrebe obrambe, cilj naj bi bil 2-odstotni BDP, kot ga predvideva Nato. Vendar je (slika 4) v obdobju 2008-2010 BDP za obrambo padel z 1,68 na 1,41 oziroma za $16 \%$, kar v nominalnem znesku pomeni skoraj 57 mio. evrov.

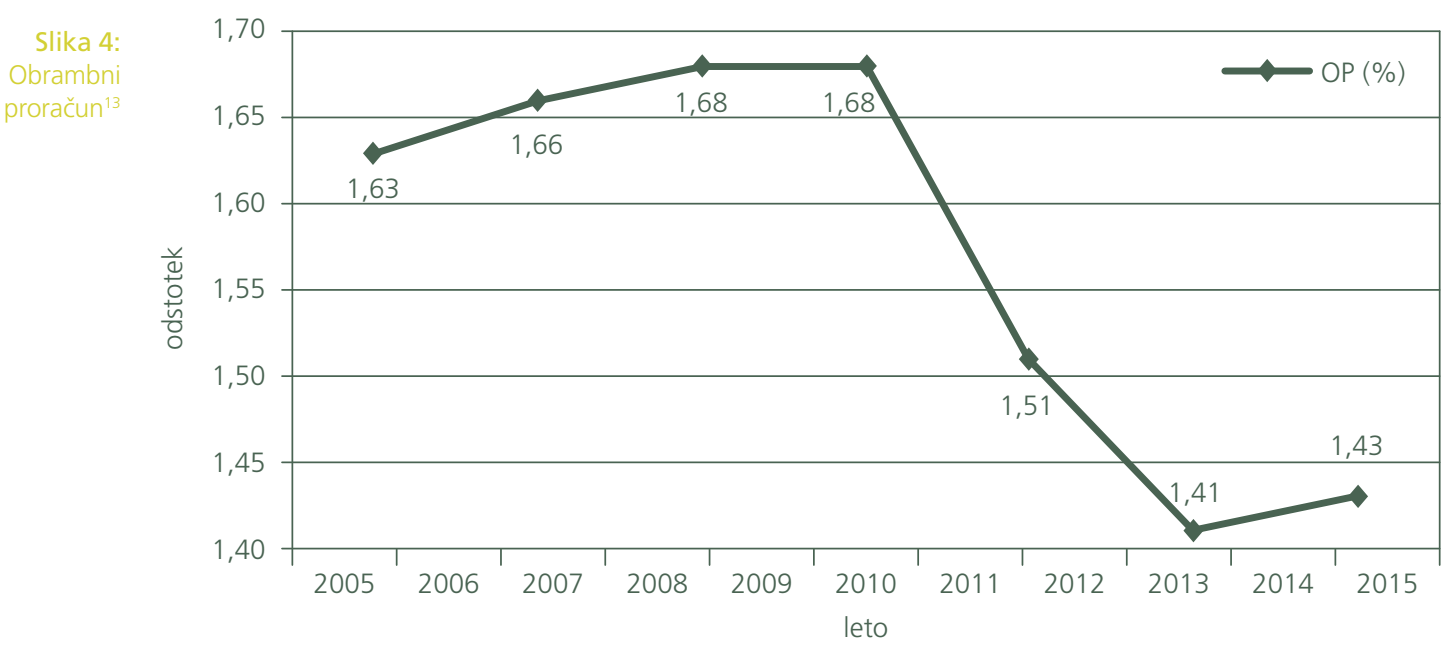

13 Podatkov za obdobje 2012-2015 ni v nobeni strokovni publikaciji. 
Zaradi občutnega zmanjšanja obrambnega proračuna kot posledice rebalansa celotnega proračuna, po podatkih Military Balance 2012, na MO Hrvaške načrtujejo prolongiranje modernizacije oborožitvenih sistemov ${ }^{14}$, za katero trenutno namenjajo le $5 \%$ obrambnega proračuna, in odprodajo nepremičnin. Posegi v stroške in plače pripadnikov hrvaške vojske, za katere se namenja okoli $70 \%{ }^{15}$ obrambnega proračuna, trenutno niso predvideni.

Prednostne naloge na obrambnem področju skladno z razpoložljivimi finančnimi viri so:

1. Tudi po sprejemu v Nato se skladno z dolgoročnim načrtom razvoja nadaljuje posodobitev hrvaške vojske, ki ima za cilj doseganje visoke stopnje povezljivosti in integracije v Nato in EU-strukture.

2. Prenova in dokončanje prestrukturiranja MO v smislu izboljšanja zmogljivosti za upravljanje obrambnega resorja skladno s standardi Nata. Med drugim se predvideva tudi vzpostavitev Poveljstva združenih sil skladno s standardi Nata, ki naj bi bilo odgovorno za celovito integrirano načrtovanje in vodenje operacij.

3. V pripravi so osnutki novih strateških in doktrinarnih dokumentov, kot so nacionalnovarnostna strategija, obrambna in vojaška strategija, posodabljanje dolgoročnega načrta razvoja idr.

4. Nadaljuje se prilagajanje standardom Nata predvsem na področju upravljanja s človeškimi viri in obrambnega načrtovanja. Dolgoročni načrt razvoja 20062015 predvideva ukinitev klasične rezervne sestave in uvedbo prostovoljne pogodbene rezerve v velikosti 6000 pripadnikov.

\section{VPLIV FINANČNIH VIROV NA OBRAMBNE ZMOGLJIVOSTI REPUBLIKE SLOVENIJE}

V Republiki Sloveniji je nosilec opravljanja nalog na področjih obrambnega sistema in sistema varstva pred naravnimi in drugimi nesrečami Ministrstvo za obrambo (v nadaljevanju MO), ki je poleg vojaške obrambe, ki jo izvaja samostojno ali v sestavi zavezništva Slovenska vojska, pristojno tudi za civilno obrambo. V obrambni sistem se z izvajanjem dejavnosti, ki prispevajo k obrambi države, vključujejo tudi drugi državni organi, organi lokalnih skupnosti ter civilnodružbene organizacije, ki so posebnega pomena za obrambo. Predsednik republike je po ustavi vrhovni poveljnik obrambnih sil, ki jih sestavlja Slovenska vojska.

Na podlagi analize ključnih finančnih kazalnikov obrambnega sistema Republike Slovenije, ki zagotavljajo izvajanje njegovega poslanstva in nalog, predstavljam ugotovitve:

\footnotetext{
${ }_{14}$ Od večjih naročil je načrtovan nakup 12 večnamenskih letal in patruljne ladje.

${ }^{15}$ Dolgoročni razvojni načrt za obdobje 2006-2015 sicer načrtuje zmanjševanje teh stroškov, in sicer na največ 50 $\%$.
} 


\begin{tabular}{|c|c|c|c|c|c|c|c|c|}
\hline \multirow{5}{*}{$\begin{array}{r}\text { Tabela 5: } \\
\text { Ključni kazalniki } \\
\text { obrambnega } \\
\text { sistema Slovenije }\end{array}$} & $\begin{array}{l}\text { Finančni } \\
\text { kazalniki }\end{array}$ & 2005 & 2006 & 2007 & 2008 & 2009 & 2010 & 2011 \\
\hline & BDP & $27 \mathrm{mlrd}$. & 29,4 mlrd. & 31,6 mlrd. & 37 mlrd. & $35,4 \mathrm{mlrd}$. & $36,5 \mathrm{mlrd}$. & $35,6 \mathrm{mlrd}$ \\
\hline & $\mathrm{BDP} p \mathrm{c}$ & 13,3 & 14,6 & 15,6 & 20 & 17,6 & 19,6 & 17,3 \\
\hline & $\mathrm{OP}$ & 396 mio. & 452 mio. & 525 mio. & 593 mio. & 589 mio. & 537 mio. & 462 mio. \\
\hline & OP (\%) & 1,46 & 1,53 & 1,66 & 1,6 & 1,66 & 1,47 & 1,29 \\
\hline
\end{tabular}

V celotnem primerjanem obdobju je imela Slovenija razmeroma visok BDP s pozitivnim trendom vse do leta 2009, ko je leta 2011 ugotavljala padec obrambnega proračun na vsega 1,29 \% BDP oziroma za 22,3 \%. Od tega znašajo vojaški izdatki le 0,99 \% BDP. Gledano v nominalnem znesku je obrambni proračun leta 2011 skoraj enak finančnim sredstvom, ki so bila namenjena za potrebe obrambe leta 2006. Z zniževanjem proračunskih sredstev se zmanjšujejo tudi finančna sredstva, namenjena za delovanje SV, kar prikazuje diagram finančnih sredstev SV (FNSV). Tudi Slovenijo je doletela gospodarska in finančna kriza, ki je imela vpliv tudi na višino obrambnega proračuna. Smernice ne kažejo na povišanje oziroma se do leta 2014 predvideva še dodatno znižanje na 1,20 \% BDP oziroma za dodatni padec $\mathrm{v}$ višini 7 \%. Od tega bi znašali vojaški izdatki le 0,88 \% BDP. Šele leta 2015 naj bi se BDP za obrambo začel postopoma dvigovati, in sicer na 1,21 \% BDP, in tako bi se vojaški izdatki dvignili na $0,97 \%$ BDP.

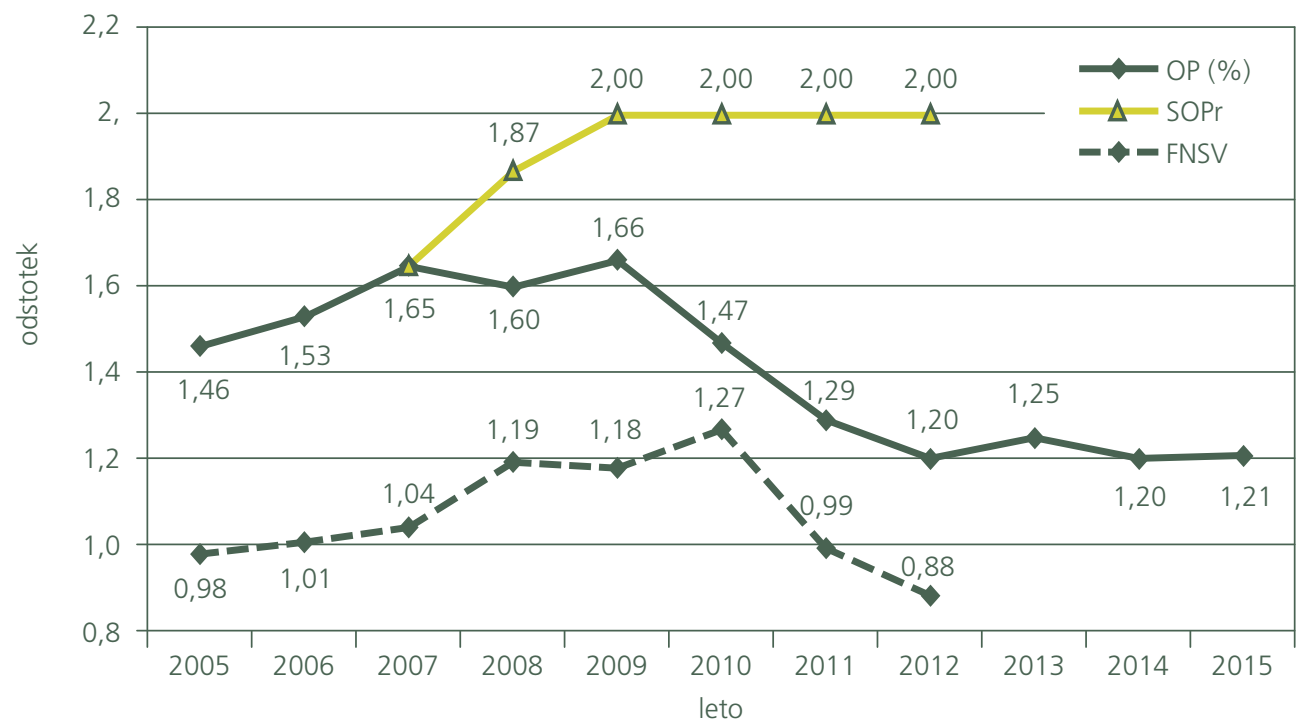

${ }_{16}$ Pri Sloveniji so prikazani načrtovani finančni viri, ki izhajajo iz Srednjeročnega obrambnega programa (v nadaljevanju SOPr) 2005-2010 in veljavnega SOPr 2007-2012, predloga Vlade za rebalans proračuna za leto 2012 ter dodatno še projekcije do leta 2015, ki izhaja iz predloga SOPr 2011-2016. 
Padajoča krivulja finančnih sredstev za obrambne namene pomeni za Slovenijo še večjo težavo, saj se je s hitrim prehodom iz delovno intenzivne obvezniške vojske prešlo na finančno intenziven koncept poklicne vojske. To sicer ne pomeni, da je poklicna vojska v nominalnem finančnem smislu dražja od obvezniške vojske, sta pa njeni učinkovitost in operabilnost večinoma odvisni od kakovosti oborožitve in opreme oziroma razpoložljivih finančnih virov za razvoj, izgradnjo in vzdrževanje njenih zmogljivosti. Nadaljevanje negativnega trenda lahko dolgoročno vpliva na vse pozitivne učinke, ki jih obrambni sistem in SV dosegata s prehodom na poklicno vojsko.

Prednostne naloge na obrambnem področju skladno z razpoložljivimi finančnimi viri so:

1. Preučiti ambicije in prednostne naloge glede na Resolucijo o splošnem dolgoročnem programu razvoja in opremljanja Slovenske vojske do leta 2025 ter določiti minimalne standarde zagotavljanja nacionalne varnosti in izvajanja zakonsko določenih nalog.

2. Nadaljevanje reform, tudi v SV, skladno s strateško usmerjevalnimi dokumenti, ter izdelava SOPr 2013-2018. Uporaba celostnega pristopa pri načrtovanju in porabi razpoložljivih finančnih sredstev za razvoj, izgradnjo in vzdrževanje zmogljivosti.

3. Pripraviti izhodišča za pogajanja z zavezništvom glede novega paketa ciljev zmogljivosti. Racionalizirati obseg usposabljanja in mednarodnega delovanja v smislu prilagajanja zunanjepolitičnih in mednarodnih obveznosti Slovenije v povezavi z uporabo SV v mednarodnih operacijah in misijah, skladno z razpoložljivimi, predvsem finančnimi viri. Nadaljevanje integracije v strukture Nata in obrambnega sistema EU ter ostati aktiven dejavnik na področju operacij $\mathrm{v}$ podporo miru in stabilnosti ostaja nacionalna prednostna naloga.

4. Ureditev in izpopolnitev sistema kriznega upravljanja in zagotavljanja civilnih zmogljivosti v povezavi z dosedanjo ureditvijo civilne obrambe.

V nadaljevanju predstavljam še grafični prikaz analize ključnih finančnih kazalnikov izbranih držav v primerjavi s Slovenijo ${ }^{17}$.

Iz grafikona (slika 6) je razvidno, da se je odstotek BDP, ki ga za obrambo namenjajo izbrane države v obdobju 2005-2011, najbolj znižal v tako imenovanih novih članicah Nata. V Hrvaški z 1,63 na 1,43 (14,8 \%) in v Madžarski z 1,41 na 0,97 (31,2 \%). V Sloveniji je zaznati nihanja, ki so imela do leta 2009 pozitiven trend, nato pa znižanje na 1,29 \% BDP (-22,3 \%). Italija in Avstrija (0,75 \%) sta z nekaj odstotnimi nihanji ohranili odstotek BDP skozi celotno primerjano obdobje. Avstrija ima sicer najnižji odstotek BDP za obrambni proračun tudi v evropskem merilu. Slovenija pa med izbranimi državami za obrambne namene zagotavlja najvišji odstotek BDP, čeprav je s 462 mio. evrov daleč na zadnjem mestu.

${ }^{17}$ Podatki so povzeti po letnem poročilu MO za leto 2010. 


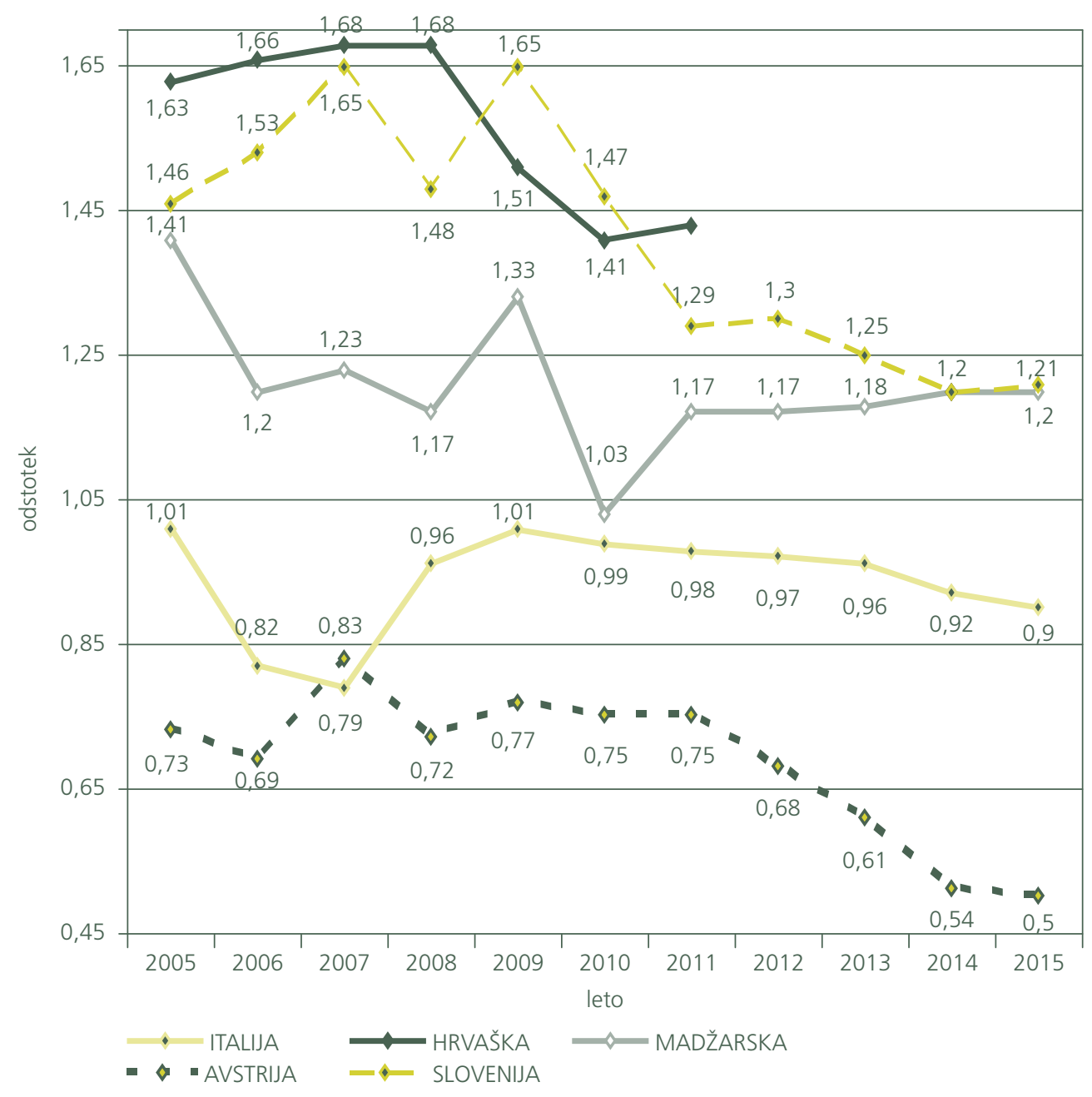

Zanimivo pa je opazovati trende gibanja višine (odstotka) obrambnega proračuna do leta 2015. Za večino držav se pričakuje še dodatno zniževanje vse do leta 2014, ko naj bi se krivulja obrnila v pozitivno smer. Za Italijo in Avstrijo se do leta 2015 ne predvideva pozitiven trend oziroma se predvideva le zmanjševanje padanja obrambnega proračuna. Za razliko od obeh držav so v Madžarski precej bolj optimistični, saj napovedujejo zviševanje višine obrambnega proračuna že od leta 2012 dalje. Za Slovenijo se predvideva, da bo krivulja obrambnega proračuna dosegla dno leta 2014, ko naj bi se obrnila v pozitivno smer.

Sklep Poleg splošno znanih ključnih dogodkov, ki so sledili koncu hladne vojne, je smiselno omeniti še konverzijo in obrambno prestrukturiranje, ki sta vzporedno potekajoča procesa, značilna za vse države, ki so pripadale blokovskim zvezam iz hladne vojne. Prav tako ju je zaznati tudi v državah, ki so bile nevtralne oziroma neuvrščene v zunanji politiki v odnosu do obeh nekdanjih blokov. 
Vse analizirane države so šle skozi proces obrambnega prestrukturiranja in ga bolj ali manj uspešno končale oziroma ga nadaljujejo. Da gre v resnici za neprekinjen proces, lahko vidimo v vseh državah, saj so reforme obrambnega sistema stalnica v vseh dolgoročnih in tudi kratkoročnih načrtih. Trend reform obrambnih zmogljivosti gre v smeri prestrukturiranja sil iz klasičnih manevrskih enot, namenjenih za obrambo ozemlja, v sodobne, hitro odzivne, prožne, mobilne, premestljive, s sodobnimi oborožitvenimi sistemi opremljene, interoperabilne in v zavezniške strukture integrirane sile, sposobne izvajanja širokega spektra operacij različnih stopenj intenzivnosti, ekspedicijskega in asimetričnega vojskovanja, delovati kot stabilizacijske sile v MOM in tudi zagotavljati vojaško obrambo nacionalnega ozemlja. Pri preoblikovanju predstavljajo sprejeti Natovi standardi eno od temeljnih vodil, s katerimi se zagotavljajo interoperabilnost, robustnost, visoka stopnja zaščite sil in mobilnosti, opremljenost in podpora. Kljub nevtralnosti tudi Avstrija ni izjema.

Ena od pomembnejših ugotovitev je, da se vse države s poklicno vojsko soočajo z znatno višjimi stroški oziroma da je poklicna vojska, ob upoštevanju vseh primerljivih parametrov, precej dražja od naborniške vojske. Stanje pa je poslabšala tudi gospodarska in finančna situacija, ki je še dodatno skrčila finančne vire, in sicer tudi za potrebe delovanja obrambnih sistemov. Skozi primerjalno analizo lahko vidimo, da nobena država ni imuna na posledice krčenja finančnih virov, razlikujejo se samo po načinu oziroma $\mathrm{v}$ katerem delu obrambnega sistema pristopajo $\mathrm{k}$ racionalizaciji. Gledano v odstotkih se za področje stroškov osebja namenja med 60 in $70 \%$ (in tudi več), za področje operativnega delovanja in pripravljenosti med 20 in 25 $\%$, za področje infrastrukture in opremljanja pa le med 10 in $15 \%$ obrambnega proračuna. Za primerjavo navajam standarde ${ }^{18}$ Nata za srednje visoko razvite države, med katere spada tudi Slovenija, ki imajo 50 \% finančnih virov za upravljanje, izobraževanje in oskrbo kadrov, $30 \%$ za operativno delovanje in pripravljenost in $20 \%$ za infrastrukturo in opremljanje.

Kot je razvidno iz analize, so najbolj prizadeti/izpostavljeni kadrovski viri oziroma nadaljuje se zmanjševanje mirnodobne sestave ter področje vzdrževanja in nabave oborožitvenih sistemov, pri čemer se večina finančnih sredstev namenja za vzdrževanje obstoječih in vse manj za nabavo novih oborožitvenih sistemov. Nakup in dobava že naročenih sredstev se velikokrat prolongira.

Kljub napovedanim reformam v nobeni od držav članic Nata višina finančnih sredstev za obrambo ne dosega 2 \% BDP, kot je bilo dogovorjeno. Predvideva se, da naj bi se krivulja višine obrambnega proračuna obrnila $\mathrm{v}$ pozitivno smer šele $\mathrm{V}$ obdobju po letu 2013. Glede na to, da gre za predvidevanja, obstaja verjetnost, da se bo negativen trend krivulje nadaljeval tudi v prihodnosti, po letu 2015.

Sedanja situacija na gospodarsko-finančnem in posledično tudi na geopolitičnovarnostnem področju je namreč zelo nepredvidljiva. Nepredvidljivost in nejasna

${ }^{18}$ Gre za standarde, katerih zagotavljanje omogoča razvoj interoperabilnih in v zavezniške strukture integriranih zmogljivosti posamezne države članice zavezništva, sposobnih stabilizacijskega delovanja v MOM. 
prihodnost delovanja EU, če se omejim zgolj na »staro« celino, ki je nastala med drugim tudi zato, da se najhujši nacionalizmi ne bi nikoli ponovili, bo zahtevala pozorno spremljanje dogajanja v izbranih in drugih državah, med drugim tudi to, na kateri točki se bo trend zmanjševanja finančnih virov za delovanje obrambnega sistema ustavil. Zgodovina nas je do zdaj kar nekajkrat opozorila, da po stopnjevanju krize v gospodarskem oziroma finančnem sektorju pride do krize tudi v političnem okolju, ki lahko vpliva na varnost in stabilnost države ter na notranjo varnostno situacijo. Stopnjevanje napetosti, pojav različnih dejavnikov negotovosti, ki lahko ob zaostrenih notranjih in mednarodnih razmerah povzročijo socialne nemire, nestabilnost ali celo odkrite konflikte, ter morebitna nezmožnost delovanja sistema notranje varnosti posamezne države pa zahteva od političnega vodstva, da za umirjanje razmer popolnoma legitimno uporabi tudi svoje oborožene sile. Morebitno brezciljno oziroma brezmejno zmanjševanje oboroženih sil lahko v kadrovskem, finančnem in v materialnem smislu privede do nezmožnosti in nesposobnosti njihovega delovanja ne le kot pomoč pri delovanju sistema notranje varnosti v omenjenem scenariju, temveč tudi za njihovo primarno nalogo, torej vojaško obrambo nacionalne države. Prav tako je lahko vprašljiva tudi sposobnost zagotavljanja pomoči in vzdržljivosti delovanja sistema varstva pred naravnimi in drugimi nesrečami.

Dolžnost držav članic zavezništva je aktivno sodelovanje na različnih področjih, temelj pa predstavljajo uspešno izvedeni procesi in aktivnosti, najprej na nacionalni ravni. Pri tem država ni izolirana in samozadostna, temveč mora pri zagotavljanju nacionalnih interesov upoštevati tudi različne dejavnike oziroma vplive iz mednarodnega okolja. Še posebno v času zmanjševanja finančnih virov je prav sodelovanje s partnerji zelo pomembno, na kar države članice Nata usmerja koncept Pametne obrambe. Države se različno prilagajajo nastali situaciji, pa vendar je treba, s ciljem varovanja nacionalnovarnostnih interesov, $\mathrm{k}$ preoblikovanju obrambnega sistema pristopiti predvsem z učinkovitim delovanjem, za kar je treba zagotoviti celovitost njegove strukture, ustrezno organiziranost, učinkovito upravljanje, vodenje in poveljevanje ter kontrolo, ustrezno stopnjo pripravljenosti in odzivnosti ter uravnotežen razvoj zmogljivosti, da bodo države sposobne integriranega in skupnega delovanja $\mathrm{v}$ nacionalnem in mednarodnem okolju.

Kot izhaja iz nacionalnih strateških in usmerjevalnih dokumentov ter zaradi zagotavljanja dolgoročne stabilnosti in varnosti bo tudi Slovenija pristopila k izpopolnitvi novih in preoblikovanju obstoječih obrambnih zmogljivosti. Ob upoštevanju predvsem nacionalnih interesov in ciljev bo morala tudi Slovenija svoj obrambni sistem prilagoditi realnim izhodiščem in dolgoročni razpoložljivosti svojih človeških, materialnih in finančnih virov, pri tem pa nedvoumno upoštevati ustavne in zakonsko določene naloge. Sistemske spremembe obrambnega sistema bodo zato morale biti osredotočene na uravnotežen razvoj, vzdrževanje in učinkovitost obrambnih sil in zmogljivosti, s katerimi bomo zagotovili skladnost in pravočasnost odzivanja na sodobne vire ogrožanja in tveganja nacionalne varnosti ter na drugi strani usmerjeni na še večjo povezljivost in operativno sposobnost v smislu zagotavljanja svojih zmogljivosti ter delovanja v okviru zavezništva, predvsem Nata in EU. V tem procesu pa 
bodo imeli poleg notranje javnosti ključno vlogo tudi širše družbeno okolje s svojimi pričakovanji in zahtevami ter ključni politični akterji v državi. Nesporno namreč ostaja dejstvo, da se bo le s pravočasnim in celovito izvedenim preoblikovanjem obrambnega sistema zagotovila še učinkovitejša podpora obrambnemu sistemu in v potrebnem obsegu tudi sistemu varstva pred naravnimi in drugimi nesrečami.

1. Anžič, A., 1997. Varnostni sistem Republike Slovenije. Uradni list RS, Ljubljana.

2. Bhagwati, J., 2004. In Defence of Globalization. Oxford: Oxford University Press.

3. Brezov̌̌ek, M., Črnčec, D., 2007. Demokratična uprava in tajnost podatkov. FDV, Ljubljana.

4. Grizold, A., 2005. Slovenija v spremenjenem varnostnem okolju, FDV, Ljubljana.

5. IHS Jane's: Defence\&Security\&Analysis

6. http://www.janes.com/products/janes/index.aspx, od 10. 1. 2012 do 1. 2. 2012.

7. Kovač, B., Kešeljević, A., Kopač, E., Svete, U., 2008. Zaščita varnostnih interesov Republike Slovenije v luči globalizacije, šifra: M5-0174. Ciljni raziskovalni projekt Znanje za varnost in mir 2006-2010. MO RS, Ljubljana.

8. Lechner, F. J., 2009. Globalization: the making of world society. Chichester, WileyBlackwell.

9. Letno poročilo Ministrstva za obrambo za leto 2010 (št. 0100-16/2011-69, z dne 16. 5. 2011).

10. Negri, A., Hardt, M., 2009. Commonwealth, Cambridge: Harvard University Press.

11. Rasmussen, A. F. Smart Defence. http://.nato.int.cps/en/natolive/78125, 5. 12. 2011.

12. Resolucija o strategiji nacionalne varnosti Republike Slovenije. Uradni list RS, št. 27/10.

13. Resolucija o splošnem dolgoročnem programu razvoja in opremljanja Slovenske vojske do leta 2025. Uradni list RS, št. 99/2010.

14. Rizman, R., 2001. Globalizacija-Izziv nove družbene paradigme. Economic and Business Review, vol. 3, str. 17-34.

15. Steele, R. D., 2002. The New Craft of Intelligence: Achieving Asymmetric Advantage in the Face of Nontraditional Threats. Carlisle, Strategic Studies Institute, U.S. Army war College.

16. Svete, U., 2005. Varnost v informacijski dobi. FDV, Ljubljana.

17. The military balance: The International Institute for Strategic Studies (IISS). 2005-2012.

18. http://www.iiss.org/publications/military-balance, od 15. 1. 2012 do 1. 4. 2012. 